\title{
Chemical and thermal characteristics of soluble polysaccharides from fruit pericarps of the Algerian Argania spinosa
}

\author{
Kadda Hachem ${ }^{\text {a, c, }{ }^{*} \text {, Kamel Eddine Boudraa }}{ }^{\text {b, c }}$, Meriem Kaid-Harche ${ }^{a}$ \\ ${ }^{a}$ Laboratoire des Productions, Valorisations Végétales et Microbiennes, Département de Biotechnologie, Université des \\ Sciences et de la Technologie d'Oran - Mohamed Boudiaf, 31000, Oran, Algeria \\ ${ }^{b}$ Laboratoire de Recherche sur les Macromolécules, Département de Physique, Faculté des Sciences, Université Abou \\ Bakr Belkaïd, 13000, Tlemcen, Algeria \\ ${ }^{c}$ Département de Biologie, Université de Saida - Dr. Moulay Tahar, 20000 Saida, Algeria \\ "Corresponding author: e-mail: hachem.kadda@univ-saida.dz; kadda46@hotmail.com
}

\begin{abstract}
Soluble polysaccharides were isolated from fruit pericarps of the Algerian Argania spinosa. The cell wall fraction was subjected to sequential extractions with $\mathrm{H}_{2} \mathrm{O}\left(2 \times 2 \mathrm{~h}\right.$ at $\left.100^{\circ} \mathrm{C}\right)$, EDTA $\left(1 \%, 6 \mathrm{~h}\right.$ at $\left.80^{\circ} \mathrm{C}\right)$ and $\mathrm{KOH}$ ( 1 and $4 \mathrm{M}, 14 \mathrm{~h}$ at $25^{\circ} \mathrm{C}$ ). The structures of the obtained polysaccharide fractions were characterized using gas chromatography (GC), infrared spectroscopy (FTIR) and differential scanning calorimetry (DSC). The presence of arabinose, galactose and rhamnose in the pectin fractions suggests the presence of rhamnogalacturonan, while the abundance of xylose in the hemicellulosic fractions indicates the presence of xylan. The DSC data revealed the endothermal behavior of all the soluble polysaccharides and only two thermal transitions, the glass transition $\left(T_{g}\right)$ and the fusion transition $\left(T_{\mathrm{f}}\right)$ have been recorded.
\end{abstract}

Keywords: Argania spinosa pericarp, Soluble polysaccharides, GC, FTIR, DSC.

\section{INTRODUCTION}

Plant cells are surrounded by a wall made up of several complex polymer structures such as polysaccharides whose nature and chemical compositions are highly variable in the plant world. These very large polymers have been valued in several fields, such as food industry ${ }^{1}$, pharmaceuticals and cosmetics ${ }^{2}$, plastics ${ }^{3}$, biocomposites ${ }^{4}$, as well as pollution remediation activities ${ }^{5}$.

The argan tree is highly adapted to growth in extreme conditions of aridity and temperature ${ }^{6}$; this tree is a very good candidate for the search for new polysaccharides with original biological, chemical and physico-chemical properties. In this context, the characterization of argan polysaccharides could lead to innovative applications.

Thus, within the framework of the valorization of Algeria's natural resources, we were interested in the soluble polysaccharide extracted from the pericarps of the fruit of the argan tree, an endemic tree ${ }^{7}$ of tropical origin which, over time, has spread outside its original geographical region to extend to the western end of the Saharo-Mediterranean transition zone; it lives in Algeria only in the wild ${ }^{8}$. Perfectly adapted to the region's climates and soils, its physiological and ecological characteristics make it the ideal tree to fight against erosion and desertification, which seriously threaten southern Algeria, 10.

The main richness of the Argan tree lies in its fruit, called "Argan nut". The flowering-fruiting cycle covers a period of 9 to 16 months depending on trees. The fruit is a berry, has a pericarp or pulp with a very hard central endocarp comprising one to several almonds ${ }^{11}$. The pericarp of the fruit is the outermost part that envelops the compound seed. It constitutes, together with the residual pressure cake of almonds and the foliage, a very important contribution to the feeding of cattle, and in particular, goats ${ }^{\mathbf{1 2}}$. To our knowledge, this is the first study devoted to soluble polysaccharides or even hemicelluloses or pectins extracted from pericarps of the Algerian argan tree. This work consisted in isolating polysaccharides by sequential fractionation of the fruit pericarps, first with hot water, then with an aqueous solution of a chelating agent (EDTA) and ultimately with an alkaline solution $(\mathrm{KOH})$. Polysaccharides were then characterized by gas chromatography (GC), Fourier transform infrared spectroscopy (FTIR) and differential scanning calorimetry (DSC).

\section{EXPERIMENTAL}

\section{Plant materials}

Argania spinosa fruit pericarps were collected from the Stidia aera (Latitude $35^{\circ} 49^{\prime} \mathrm{N}$; Longitude $0^{\circ} 02^{\prime} \mathrm{E}$ ), west coast of Northern Algeria. Fruit pericarps were dried in a ventilated oven $\left(40^{\circ} \mathrm{C}\right)$ and ground to a fine powder $(<200 \mu \mathrm{m})$.

\section{Cell wall residue preparation}

The powder obtained was treated twice with a mixture of toluene-ethanol $(\mathrm{v} / \mathrm{v})$ to remove lipids, proteins, tannins, etc., before being treated with ethanol for $2 \mathrm{~h}$ at room temperature to remove the traces of toluene. The obtained cell wall residue (CWR) was dried in a ventilated oven $\left(60^{\circ} \mathrm{C}\right)$, weighed and stored in a desiccator at room temperature.

\section{Water and chelating-soluble pectin polysaccharide}

Pectic polysaccharides were sequentially extracted from $\mathrm{CWR}$ with water $\left(2 \times 2 \mathrm{~h}\right.$ at $\left.100^{\circ} \mathrm{C}\right)$ and $1 \%$ aqueous solution of the calcium salt of ethylene diamine tetracetic acid (EDTA)containing $\mathrm{NaBH}_{4}(3 \mathrm{mg} / \mathrm{mL})(1 \%, 6 \mathrm{~h}$ at $80^{\circ} \mathrm{C}$ ). After filtration, extracts were extensively dialyzed overnight against distilled water, precipitated with ethanol, then centrifuged and finally freeze-dried. The obtained fractions were named $\mathrm{P}_{1}-\mathrm{H}_{2} \mathrm{O}$ and $\mathrm{P}_{2}$-EDTA, respectively.

\section{Alkali-soluble hemicellulose polysaccharide fraction}

The final residue resulting from pectin extraction was then treated sequentially with $500 \mathrm{~mL}$ of 1 and $4 \mathrm{M} \mathrm{KOH}$ solutions containing $\mathrm{NaBH}_{4}(3 \mathrm{mg} / \mathrm{mL})$ during $14 \mathrm{~h}$ at 
room temperature $\left(25^{\circ} \mathrm{C}\right)$. All extracts were acidified with $20 \% \mathrm{AcOH}$ to $\mathrm{pH} 6$ and extensively dialyzed overnight against distilled water (membrane cut off: 6,000-8,000 $\mathrm{Da}$ ) and concentrated with a rotary evaporator. The obtained fractions were named $\mathrm{H}_{1}-\mathrm{KOH} 1 \mathrm{M}$ and $\mathrm{H}_{2-}$ $-\mathrm{KOH} 4 \mathrm{M}$, respectively.

\section{Uronic acid determination}

The uronic acid content was determined colorimetrically at $520 \mathrm{~nm}$ with the $m$-hydroxydiphenyl assay according to Blumenkrantz and Asboe-Hansen ${ }^{\mathbf{1 3}}$ using a Beckman DU 640 spectrophotometer (Beckman Coulter, Corona, CA, USA). Glucuronic acid was used as a standard.

\section{Gas Chromatography}

The proportions of neutral monosaccharides were determined by gas chromatography (GC) of the corresponding alditol acetates according to Selvendran et al. ${ }^{\mathbf{1 4}}$.

Briefly, alditol acetates were obtained by hydrolysis of $3 \mathrm{mg}$ of sample in $0.5 \mathrm{~mL}$ of the $2 \mathrm{M}$ mixture of trifluoroacetic acid TFA/myo-inosotol (15 mg of myo-inositol weighed will be used as an internal standard in $20 \mathrm{~mL}$ TFA). The mixture was then kept at $110^{\circ} \mathrm{C}$ for $2 \mathrm{~h}$. After concentration using a rotary evaporator, the $\mathrm{pH}$ of the mixture was adjusted to 8 to 9 with aqueous ammonium hydroxide (4\%). Monosaccharides were then reduced overnight at room temperature in the presence of sodium borohydride $(10 \mathrm{mg})$. After neutralization with $50 \%$ acetic acid solution, the medium was evaporated to dryness and then co-evaporated 3 times with hydrochloric acid/methanol $(\mathrm{MeOH} / \mathrm{HCl} ; 100 / 1)$. The dry residue was acetylated with a pyridine/acetic anhydride mixture $(1 / 1 ; 1 \mathrm{~mL}) 1 \mathrm{~h}$ at reflux. Excess acetic anhydride was then cold hydrolyzed before evaporation to dryness and then co-evaporated three times after the addition of distilled water.

Alditol acetates were analyzed with a 5890A Hewlet-Packard gas chromatograph equipped with a fused silica column (30 m x $0.53 \mathrm{~mm})$ impregnated with a 2380 Suplecofilm (3\%) and a flame ionization detector (FID) coupled to a 3395 Hewlett-Packard integrator. The carrier gas used was nitrogen U. The experimental conditions were as follows:

- Injection temperature: $260^{\circ} \mathrm{C}$

- Column temperature: $195^{\circ} \mathrm{C}$ to $225^{\circ} \mathrm{C}$ in increments of $2.5^{\circ} \mathrm{C} \cdot \mathrm{min}^{-1}$.

- Detection temperature: $280^{\circ} \mathrm{C}$

- Nitrogen $\left(\mathrm{N}_{2}\right)$ flow rate: $4 \mathrm{~mL} \cdot \mathrm{min}^{-1}$

Alditol acetates were identified by comparing retention times with those of control containing the previously reduced and acetylated oses: rhamnose, fucose, xylose, arabinose, mannose, galactose and glucose as well as acetylated myo-inositol.

\section{Infrared Spectroscopy}

Soluble-polysaccharides were characterized by a Perkin Elmer 2000 FTIR model in the $400-4000 \mathrm{~cm}^{-1}$ frequency range. The number of scans was 16 with a spectral resolution of $4 \mathrm{~cm}^{-1}$. Each dose was applied once and the interval of time between the end of exposure and the infrared analysis was kept constant. Assays were repeated three times to validate the results.

\section{Differential Scanning Calorimetry}

DSC measurements were performed with a Pyris Diamond Perkin Elmer calorimeter equipped with a 2P Intracooler system allowing cooling experiments as previously described by Boudraa et al. ${ }^{15}, \mathbf{1 6}$. Briefly, samples for calorimetric measurements were prepared by introducing approximately $8 \mathrm{mg}$ of the material into an aluminum DSC pan, which was sealed to avoid evaporation effects during the temperature treatment. A rate of $10^{\circ} \mathrm{C} \cdot \mathrm{min}^{-1}$ (heating and cooling) was used in the temperature range from 20 to $250^{\circ} \mathrm{C}$. The program consisted first in cooling the sample, then in three heating and cooling cycles to take into account possible thermal events related to the history of the sample preparation. Pyris Perkin-Elmer computer software was used to determine the onset temperature of the various phase transitions. Only thermograms from the first heating scan were considered for the analysis. The DSC apparatus was calibrated using indium as standard at a heating rate of $10^{\circ} \mathrm{C} \cdot \mathrm{min}^{-1}$.

\section{RESULTS AND DISCUSSIONS}

\section{Yield and composition of monosaccharides}

Table 1, shows the monosaccharide content of each polysaccharidic fraction. The pectic nature of the $\mathrm{P}_{1}$. $-\mathrm{H}_{2} \mathrm{O}$ and $\mathrm{P}_{2}$-EDTA fractions, is confirmed by their high uronic acid contents, which are of the order of 40 to $49 \%$, respectively, with a total yield exceeding $60 \%$ of the CWR weight. $\mathrm{P}_{1}-\mathrm{H}_{2} \mathrm{O}$ and $\mathrm{P}_{2}$-EDTA fractions contain significant amounts of arabinose (72 and $75.5 \%$, respectively) followed by galactose (15 and $10 \%$, respectively) compared with other neutral sugars. These distributions suggest the existence of arabinose- and galactose-rich side chains which are commonly found in pectins. However, rhamnose was only detected in small quantities. This is certainly due to the acid stability of the glycosidic bond between a neutral sugar and a uronic acid. Xylose and glucose were detected at low levels with averages of 2 and $6 \%$, respectively. The Rha/UA ratios established for the $\mathrm{P}_{1}-\mathrm{H}_{2} \mathrm{O}$ and $\mathrm{P}_{2}$-EDTA fractions were 0.1 indicating a predominance of rhamnogalacturonans type-I (RG-I) over homogalacturonans (HG) ${ }^{\mathbf{1 7}}$.

Table 1. Yields and monosaccharide composition of soluble polysaccharides determined form alditol acetates by GC

\begin{tabular}{|c|c|c|c|c|c|c|c|c|c|}
\hline \multirow{2}{*}{ Fraction } & \multirow{2}{*}{ Yield $^{a}$} & \multicolumn{7}{|c|}{ Monosaccharide composition ${ }^{b}$} & \multirow{2}{*}{$\mathrm{UA}^{\mathrm{c}}$} \\
\hline & & Rha & Fuc & Ara & Xyl & Man & Gal & Glc & \\
\hline $\mathrm{P}_{1}-\mathrm{H}_{2} \mathrm{O}$ & 32.3 & 5 & $\operatorname{tr}$ & 72 & 3 & nd & 15 & 5 & 39.4 \\
\hline$P_{2}$-EDTA & 28.5 & 6 & $\operatorname{tr}$ & 75.5 & 1.5 & nd & 10 & 7 & 48.9 \\
\hline $\mathrm{H}_{1}-\mathrm{KOH} 1 \mathrm{M}$ & 8.8 & 4 & 4 & 18 & 53 & nd & 9 & 14 & 19.3 \\
\hline $\mathrm{H}_{2}-\mathrm{KOH} 4 \mathrm{M}$ & 9.7 & 4 & 2 & 11 & 47 & nd & 7 & 29 & 26.6 \\
\hline
\end{tabular}

${ }^{a}$ Expressed as $\%$ of $05 \mathrm{~g}$ of the CWR dry weight; ${ }^{\mathrm{b}}$ Percentage of peak area relative to total peak areas, determined by GC; UA: uronic acid; Rha: rhamnose; Ara: arabinose; Xyl: xylose; Glc: glucose; Gal: galactose; Man: mannose; Fuc: fucose; ${ }^{c}$ Expressed as relative weight percentages; $\operatorname{tr}=$ trace; $n d=$ not determined 
However, rhamnogalacturonans type-II (RG-II) could also be present. Nevertheless, these data differ from those about pectins isolated from the Moroccan Argan fruit pulp $(A F P)^{18}$. Indeed, according to Stitt \& Zeeman ${ }^{19}$, changes in the levels of different cell wall components could be influenced by environmental factors such as different irradiances, day lengths, $\mathrm{CO}_{2}$ concentrations, nutrient and water supplies and/or genetic and biochemical factors such as the various signaling pathways.

These results are very similar to those obtained on the same tissue, including crude polysaccharides from the pericarps of longan fruits ${ }^{20}$, and from the pericarps of acorns of Quercus sp. ${ }^{21}$.

The alkaline fractions $\mathrm{H}_{1}-\mathrm{KOH} 1 \mathrm{M}$ and $\mathrm{H}_{2}-\mathrm{KOH} 4 \mathrm{M}$ were recovered with total yields of at least 19\%; they consisted mainly of xylose (53 and $47 \%$, respectively) and uronic acids in significant proportions (19.3 and $26.6 \%$, respectively). These results suggest that these fractions consist of acid xylans. However, the presence of arabinose in appreciable amounts (18\%) suggests the presence of arabinoglucuronoxylans $\mathrm{s}^{6}$. Nevertheless, the presence of hemicelluloses of the xyloglucan cannot be excluded (Xyl/Glu ratios of 4 and 2 were found in $\mathrm{H}_{1}$. $-\mathrm{KOH} 1 \mathrm{M}$ and $\mathrm{H}_{2}-\mathrm{KOH} 4 \mathrm{M}$, respectively); representing the predominant family of hemicelluloses, xyloglucans- a are mainly found in dicotyledons ${ }^{22}$.

Xylans of the Algerian Argan tree pericarps consist of acidic polysaccharides as shown by their content in uronic acids. These results are comparable with those already reported about the seed pericarp of the Argania spinosa fruit ${ }^{23}$ as well as about xylans of the seed pericarp of the Opuntia ficus-indica prickly pear fruit ${ }^{[24]}$. Nevertheless, differences have been highlighted in the case of Quercus sp. pericarps ${ }^{21}$.

\section{FTIR spectroscopy analysis}

FT-IR spectra of the soluble polysaccharides obtained in the different fractions are shown in Figure 1. IR spectra profiles of pectic fractions $\mathrm{P}_{1}-\mathrm{H}_{2} \mathrm{O}$ and $\mathrm{P}_{2}$-EDTA are similar. All of these spectra displayed the characteristic pectin bands ${ }^{25}$ at $3460 \mathrm{~cm}^{-1}\left(v_{(\mathrm{OH})}\right), 2929 \mathrm{~cm}^{-1}\left(v_{(\mathrm{CH})}\right)$,
$1737 \mathrm{~cm}^{-1}\left(v_{(\mathrm{C}=\mathrm{O}) \mathrm{COOMe}_{\mathrm{COO}}}\right), 1415 \mathrm{~cm}^{-1}\left(v_{\left(\mathrm{COO}^{-}\right)}\right), 1325$ $\mathrm{cm}^{-1}\left(v_{(\mathrm{CH})}\right), 1146 \mathrm{~cm}^{-1}\left(v_{(\mathrm{COC})}\right.$ glycosidic bond, ring), $1098 \mathrm{~cm}^{-1}\left(v_{(\mathrm{C}-\mathrm{C})}\right)$ and $1014 \mathrm{~cm}^{-1}\left(v_{(\mathrm{C}-\mathrm{O})}\right)$.

FTIR spectra of hemicellulosic fractions $\mathrm{H}_{1}-\mathrm{KOH} 1 \mathrm{M}$ and $\mathrm{H}_{2}-\mathrm{KOH} 4 \mathrm{M}$ showed the same absorption bands, characteristic of hemicellulosic type xylans $(1 \rightarrow 4)$, with a maximum absorption band at $1025 \mathrm{~cm}^{-1}\left(v_{(\mathrm{C}-\mathrm{OH})}\right)^{26}$. The peak intensity ratio between the band at $1402 \mathrm{~cm}^{-1}$ $\left(v_{(\mathrm{C}-\mathrm{O})}\right)$ and those at $1554 \mathrm{~cm}^{-1}\left(v_{(\mathrm{C}=\mathrm{O})}\right)$ is larger in the spectrum of the $\mathrm{H}_{2}-\mathrm{KOH} 4 \mathrm{M}$ fraction than the corresponding ratio in the $\mathrm{H}_{1}-\mathrm{KOH} 1 \mathrm{M}$ fraction spectrum. These results confirm the acidic character of all the extracted hemicelluloses ${ }^{6,27}$.

In addition, other bands of medium intensity have been observed at $1642-1604 \mathrm{~cm}^{-1}$ which are due to $v_{(\mathrm{C}=\mathrm{C})}$ aromatic ring ${ }^{28}$ suggesting the presence of residual lignin linked to the different soluble polysaccharides obtained.

\section{Thermal characteristics analysis}

Among the most experimental approaches to estimate the thermal behavior of a polymer is the determination of the glass transition temperature of the considered system by means of differential scanning calorimetry (DSC). This technique allows the tracking of major changes in the structural organization of the studied polymer.

Three duplicated samples have been used to identify each polymer. After the heating/cooling ramps were done, it was possible to draw, from the resulting curves, the tangents to the curve of the heat flow, and the glass transition temperature of the polymer can be determined from the Half Cp Extrapolated point of the transition range of the curves. Having obtained similar curves for the three tests for each sample, only one curve for each composition is presented. The results are collected in Fig. 2.

Usually, every sample only presents two thermal transitions, the glass transition and the fusion transition. The samples $\mathrm{P}_{1}-\mathrm{H}_{2} \mathrm{O}$ and $\mathrm{P}_{2}$-EDTA practically possess the same glass transition temperature at around $65^{\circ} \mathrm{C}$. By increasing the temperature, we notice that the $\mathrm{P}_{2}$-EDTA sample first melts around $125^{\circ} \mathrm{C}$ followed by $\mathrm{P}_{1}-\mathrm{H}_{2} \mathrm{O}$.
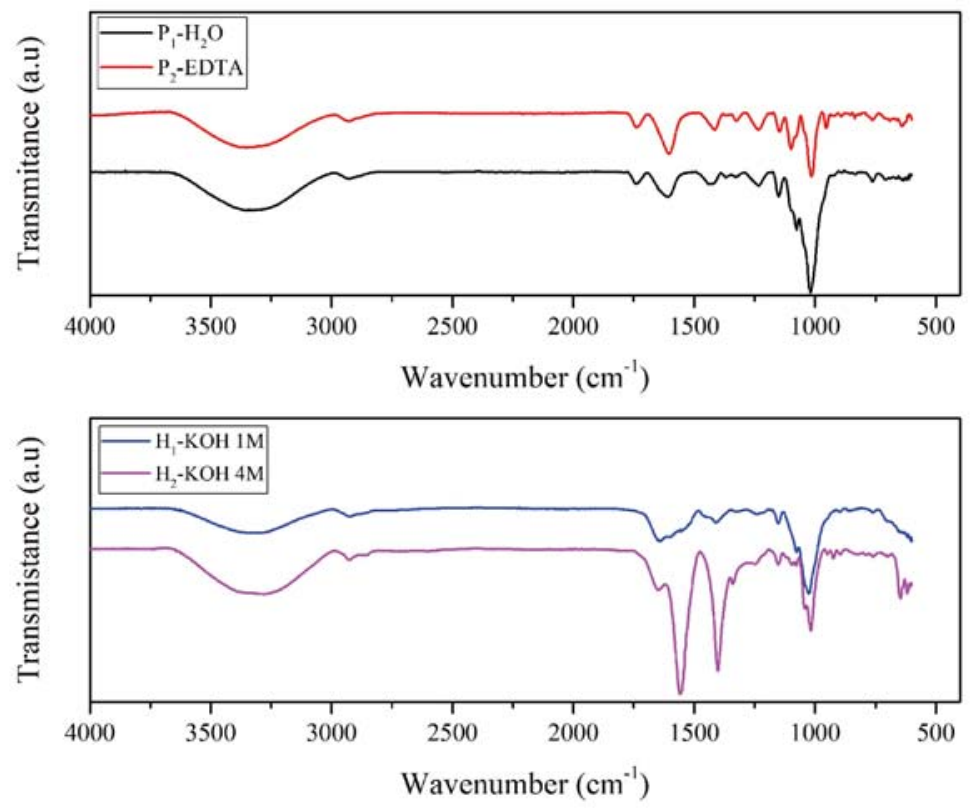

Figure 1. FTIR spectra of the different soluble-polysaccharides 

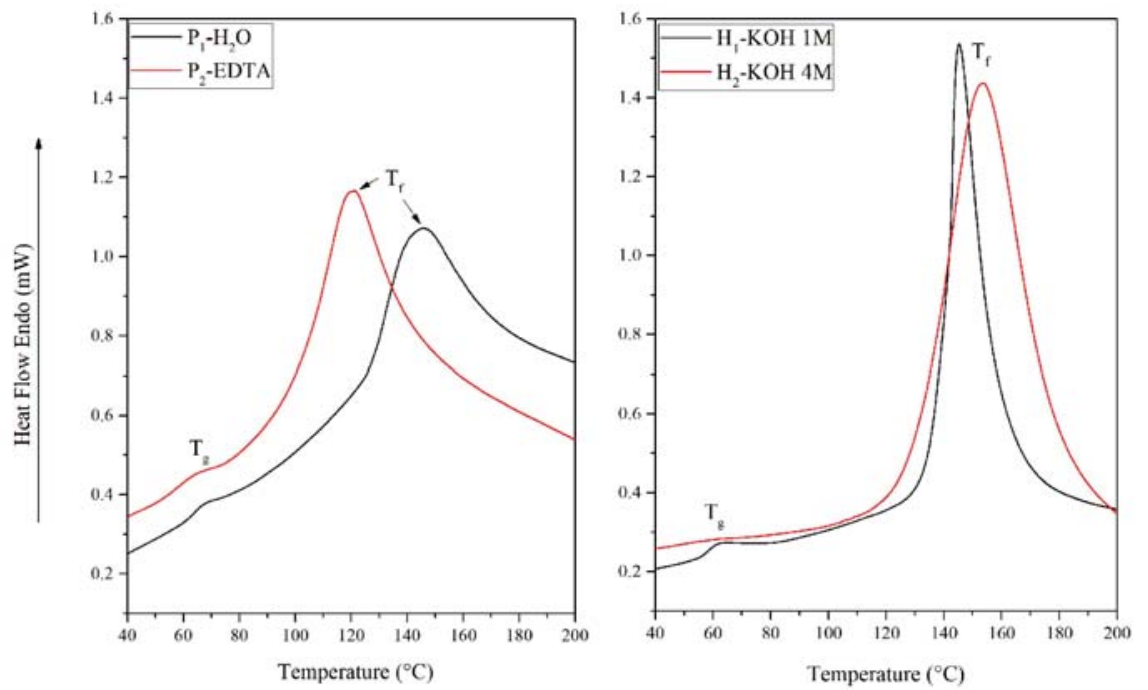

Figure 2. DSC of the different soluble-polysaccharides at a heating rate of $10^{\circ} \mathrm{C} \mathrm{min}-1$

The same remarks can be drawn from the curve displaying the thermal behavior of the $\mathrm{H}_{1}-\mathrm{KOH} 1 \mathrm{M}$ and $\mathrm{H}_{2}-\mathrm{KOH} 4 \mathrm{M}$ samples. Glass transition temperatures of $68^{\circ} \mathrm{C}$ have been reported for polysaccharides sequentially extracted from the leaves of Vaccinium bracteatum Thunb ${ }^{29}$.

DSC revealed a clear endothermic signal in all soluble-polysaccharides here studied, due to the disintegration of intramolecular interactions and to degradation ${ }^{30}$, whereas the endothermic peak presented a lower intensity in $\mathrm{P}_{1}-\mathrm{H}_{2} \mathrm{O}$ and $\mathrm{P}_{2}$-EDTA, suggesting that the corresponding structures could imply less hydrogen bonds, probably due to the presence of substituents ${ }^{31}$. An alternative or complementary explanation for endothermic behavior is endothermic devolatilization. According to Ball et al. the complete decomposition of polysaccharides could be attributed to the rapid devolatilization reactions, leading to very little solid residue, while the exothermic behavior of the high solid residue generated by pyrolysis could be attributed to carbonization ${ }^{32}$.

The endothermic behavior of hemicelluloses and pectins has been reported only rarely before, to the knowledge of the authors. However, an exothermic behavior, which could be the result of the uronic acid decomposition of sugar, has been observed following the chemical decomposition of certain biomasses ${ }^{33}$ 34, 28 . Indeed, Werner et al. pointed out that that the carboxylic acids groups (-COOH) are prone to undergo decarboxylation resulting in carbon dioxide production and exothermic enthalpy changes ${ }^{34}$.

\section{CONCLUSIONS}

The present study deals with the chemical and thermal properties of the different soluble polysaccharides extracted from the pericarp of the Algerian argan fruit. We were able to see the difference between the chemical structures thanks to the identification carried out by gas chromatography and Fourier transform infrared spectroscopy. These differences in the chemical structures were not reflected by the thermal diagrams obtained with the DSC technique. The diagrams showed only two thermal transitions, which are the glass transition temperature and the fusion transition with endothermic behavior. In the future, other additional fractionation and purification methods may be considered to improve the thermal stability of the extracted polymers.

\section{ACKNOWLEDGMENTS}

The authors are grateful for the financial support received from the Department of Biology, University of Saida Dr. Moulay Tahar, Algeria. The authors acknowledge Dr. Michel Guilloton for his help in manuscript editing

\section{LITERATURE CITED}

1. Coma, V. (2013). Polysaccharide-based biomaterials with antimicrobial and antioxidant properties. Polímeros. 23(3), 287-297. DOI: 10.4322/polimeros020ov002.

2. Majee, S.B., Avlani, D. \& Biswas, G.R. (2017). Pharmacological, pharmaceutical, cosmetic and diagnostic applications of sulfated polysaccharides from marine algae and bacteria. Afr. J. Pharm. Pharmacol. 11(5), 68-77. DOI: 10.5897/AJPP2016.4695.

3. Castro, J.P.L.d., Costa, L.E.C. , Pinheiro, M.P., Francisco, T.d.S., Vasconcelos, P.H.M.d., Funari, L.M., Daudt, R.M., Santos, G.R.C.d., Cardozo, N.S.M. \& Freitas, A.L.P. (2018). Polysaccharides of red alga Gracilaria intermedia: structure, antioxidant activity and rheological behavior, Polímeros. 28(2), 178-186. DOI: 10.1590/0104-1428.013116.

4. Khenblouche, A., Bechki, D., Gouamid, M., Charradi, K., Segni, L., Hadjadj, M. \& Boughali, S. (2019). Extraction and characterization of cellulose microfibers from Retama raetam stems. Polímeros. 29(1). e2019011. DOI: 10.1590/01041428.05218 .

5. Mébarki, M., Hachem, K. \& Kaid-Harche, M. (2019). Lignocellulosic fraction of the pericarps of the acorns of Quercus suber and Quercus ilex: isolation, characterization, and biosorption studies in the removal of copper from aqueous solutions. Pol. J. Chem. Tech., 21, 3, 40-47, DOI: 10.2478/pjct-2019-0028.

6. Hachem, K., Faugeron, C., Kaid-Harche, M. \& Gloaguen, V. (2016). Structural Investigation of Cell Wall Xylan Polysaccharides from the Leaves of Algerian Argania spinosa. Molecules. 21(11), 1587. DOI: 10.3390/molecules21111587.

7. Peltier, J.P. (1983). Les séries de l'arganeraie steppique dans le Souss (Maroc). Ecol. Mediterr. 9, 77-88.

8. Kechairi, R. \& Benmahioul, B. (2019). Comportement des plants d'Arganier (Argania spinosa L. Skeels, Sapotaceae) au sud-ouest Algérien (Tindouf, Bechar et Adrar). Int. J. Environ. Stud. 76(5), 800-814. DOI: 10.1080/00207233.2019.1602378. 
9. Kechairi, R. \& Abdoun, F. (2016). État des lieux cartographiques de l'arganier Argania spinosa (L.) Skeels (Sapotaceae) en Afrique Nord-Occidentale (Algérie et Sahara Occidental). Int. J. Environ. Stud. 73(2), 286-293. DOI: 10.1080/00207233.2016.1148448.

10. Sebaa, H.S. \& Harche, M.K. (2014). Anatomical structure and ultrastructure of the endocarp cell walls of Argania spinosa (L.) Skeels (Sapotaceae). Micron. 67, 100-106. DOI: 10.1016/j.micron.2014.07.001.

11. Kenny, L. (2007). Atlas de l'arganier et de l'arganeraie. Agadir: Institut Agronomique et Vétérinaire.

12. Merouane, A., Noura, A. \& Khelifa-Zoubir, M. (2014). In vitro estimate of the energy value of argan from Algeria. Livest Res. Rural Dev. 26(5), 2014.

13. Blumenkrantz, N. \& Asboe-Hansen, G. (1973). New method for quantitative determination of uronic acids. Anal. Biochem. 54(2), 484-489. DOI: 10.1016/0003-2697(73)90377-1.

14. Selvendran, R.R., March J.F. \& Ring, S.G. (1979). Determination of aldoses and uronic acid content of vegetable fiber. Anal. Biochem. 96(2), 282-292. DOI: 10.1016/00032697(79)90583-9.

15. Boudraa, K., Bouchaour, T. \& Maschke, U. (2019). Thermal analysis of interpenetrating polymer networks through molecular dynamics simulations: a comparison with experiments. J. Therm. Anal. Calorim. 140, 1845-1857. DOI: 10.1007/ s10973-019-08898-y.

16. Boudraa, K.E., Bouchaour, T., Beyens, C. \& Maschke, U. (2020). Novel interpenetrating polymer network composed of poly(butyl acrylates) and poly(ethyl-hexyl acrylate). Int. J. Polym. Anal. Char. 25(1), 18-33. DOI: 10.1080/1023666x.2020.1737467.

17. Schols, H.A. \& Voragen, A.G.J. (1996). In J. Visser, \& A.G.J. Voragen, (Eds.), Pectins and pectinases (pp. 3-19).: Amsterdam: Elsevier Science BV.

18. Aboughe-Angone, S., Nguema-Ona, E., Ghosh, P., Lerouge, P., Ishii, T., Ray, B. \& Driouich, A. (2008). Cell wall carbohydrates from fruit pulp of Argania spinosa: structural analysis of pectin and xyloglucan polysaccharides. Carbohydr. Res. 343(1), 67-72. DOI: 10.1016/j.carres.2007.10.018

19. Stitt, M. \& Zeeman, S.C. (2012). Starch turnover: pathways, regulation and role in growth. Curr. Opin. Plant Biol. 15(3), 282-292. DOI: 10.1016/j.pbi.2012.03.016.

20. Yang, B., Jiang, Y., Zhao, M., Chen, F., Wang, R., Chen, Y. \& Zhang, D. (2009). Structural characterisation of polysaccharides purified from longan (Dimocarpus longan Lour.) fruit pericarp. Food Chem. 115(2), 609-614. DOI: 10.1016/j. foodchem.2008.12.082.

21. Mébarki, M., Hachem, K., Faugeron-Girard, C., Mezemaze, R.H. \& Kaid-Harche, M (2019). Extraction and analysis of the parietal polysaccharides of acorn pericarps from Quercus trees. Polímeros. 29(3), e2019044. DOI: 10.1590/01041428.06119.

22. Hu, R., Xu, Y., Yu, C., He, K., Tang, Q., Jia, C., He, G., Wang, X., Kong, Y. \& Zhou, G. (2017). Transcriptome analysis of genes involved in secondary cell wall biosynthesis in developing internodes of Miscanthus lutarioriparius. Sci. Rep. 7(1), 9034. DOI: 10.1038/s41598-017-08690-8.

23. Habibi, Y. \& Vignon, M.R. (2005). Isolation and characterization of xylans from seed pericarp of Argania spinosa fruit. Carbohydr. Res. 340(7), 1431-1436. DOI: 10.1016/j. carres.2005.01.039. PMid:15854618.

24. Habibi, Y., Heux, L., Mahrouz, M. \& Vignon, M.R. (2008). Morphological and structural study of seed pericarp of Opuntia ficus-indica prickly pear fruits. Carbohydr. Polym. 72(1), 102-112. DOI: 10.1016/j.carbpol.2007.07.032.

25. Taboada, E., Fisher, P., Jara, R., Zúñiga, E., Gidekel, M., Cabrera, J.C., Pereira, E., Gutierrez-Moraga, A., Villalonga, R. \& Cabrera, G. (2010). Isolation and characterisation of pectic substances from murta (Ugni molinae Turcz) fruits. Food Chem. 123(3), 669-678. DOI: 10.1016/j.foodchem.2010.05.030.

26. Kacurakova, M., Wellner, N., Ebringerova, A., Hromidkova, Z., Wilson, R.H. \& Belton, P.S. (1999). Characterization of xylan-type polysaccharides and associated cell wall components by FT-IR and FT-raman spectroscopies. Food Hydrocoll. 13(1), 35-41. DOI: 10.1016/S0268-005X(98)00067-8.

27. Hachem, K., Faugeron-Girard, C., Kaid-Harche, M. \& Gloaguen, V. (2017). Acid hydrolysis of xylan polysaccharides fractions isolated from argan (Argania spinosa) leaves. Cogent Chem. 3, 1370684. DOI: 10.1080/23312009.2017.1370684.

28. Yang, H., Yan, R., Chen, H., Lee, D.H. \& Zheng, C. (2007). Characteristics of hemicellulose, cellulose and lignin pyrolysis. Fuel. 86(12-13), 1781-1788. DOI: 10.1016/j. fuel.2006.12.013.

29. Xu, Q.X., Shi, J.J., Zhang, J.G., Li, L., Jiang, L. \& Wei, Z.J. (2016). Thermal, emulsifying and rheological properties of polysaccharides sequentially extracted from Vaccinium bracteatum Thunb. leaves. Int. J. Biol. Macromol. 93, 1240-1252. DOI: 10.1016/j.ijbiomac.2016.09.098

30. Sun, X.F., Sun, R.C., Tomkinson, J. \& Baird, M.S. (2003). Preparation of sugarcane bagasse hemicellulosic succinates using NBS as catalyst. Carbohydr. Polym. 53(4), 483-495. DOI: 10.1016/S0144-8617(03)00150-4.

31. Winkler, H., Vorwerg, W. \& Rihm, R. (2014). Thermal and mechanical properties of fatty acid starch esters. Carbohydr. Polym. 102, 941-949. DOI: 10.1016/j.carbpol.2013.10.040.

32. Ball, R., McIntosh, A.C. \& Brindley, J. (2004). Feedback processes in cellulose thermal decomposition: implications for fire-retarding strategies and treatments. Combust. Theor. Model. 8(2), 281-91. DOI: 10.1088/1364-7830/8/2/005.

33. Di Blasi, C., Branca, C., Sarnataro, F.E. \& Gallo, A. (2014). Thermal Runaway in the Pyrolysis of Some Lignocellulosic Biomasses. Energ. Fuel. 28(4), 2684-2696. DOI: 10.1021/ ef500296g.

34. Werner, K., Pommer, L. \& Broström, M. (2014). Thermal decomposition of hemicelluloses. J. Anal. Appl. Pyrol. 110, 130-137. DOI: 10.1016/j.jaap.2014.08.013. 